\title{
Mouse Infestation Disturbances and Preservation Activities at the Library
}

\author{
Danang Dwijo Kangko* and Andrew T. Thren \\ Binus University International \\ Jl. Hang Lekir I No.6 Jakarta \\ dkangko@binus.edu and athren@binus.edu
}

\begin{abstract}
Information is recorded in information media that is collected by library management. The information will be lost if the collections are damaged. The library functions to preserve collections to ensure information access sustainability. One threat is mouse infestation. Not much attention has been given to the effects of mouse infestation disturbances and how mice can potentially damage collections. This research aims to find out how and why mouse disruptions occur in the library and what preservation measures are taken by the library to counter this. This research is a case study conducted in the Indonesian Politics Study Center. This study reveals that mouse infestation disruptions are not too much of a concern at the Indonesian Politics Study Center, as preservation activities have not been conducted extensively.
\end{abstract}

Keywords: library management, mouse infestations, preservation activities.

\section{Introduction}

Libraries manage collections to fulfill library patrons' information needs. A library collection can be defined as "all information in the form of written works, printed works, and/or recorded materials in various media that have educational value, which are collected, processed, and provided." 
(Indonesia, 2007) Library collections need to be preserved. Preserving library collections is one of the functions of a library. This is contained in Amendment Number 43, 2007, regarding Libraries Chapter I Article 3, which is "Libraries function as a means of education, research, preservation, information, and recreation to improve national intelligence and endurance".

Pelestarian (preservation) originates from the word lestari (preserve) (Sanskrit language), which means fostered. Rachman (2016) postulates that,

"Preservation is not only related to physical improvements, but it is an intellectual content preservation effort, which involves environmental management (policies and strategies), information recording improvement methods and techniques (conservation and restoration), as well as human resource development (librarians) in fostering and preserving information media or library materials from various damage and destructive factors."

Library collections must be preserved, in order that the information recorded in its media is not lost or damaged. Thus, library collections can be continued to be used, and the information found within them can be accessed by future generations. "Preservation of library materials depends on several factors, including the quality of basic materials, the storage environment, as well as other factors like animals, insects, mold, and humans." (Martoatmodjo, 1999) One kind of animal that threatens the preservation of library collections is rodents such as mice.

Mouse infestation disturbances are classified as a biological factor that damages library collections (Muljono, 1996). Mouse infestation disturbances are not a primary factor in causing damage to library collections. This makes libraries occasionally disregard engaging in preservation activities when faced with mouse infestation disturbances. Nevertheless, mouse infestation disturbances cannot be put to the wayside, because this kind of a pest is known to be disruptive and difficult to eradicate. This rodent has a destructive nature and gnaws on any objects, including library collections and equipment.

This research strives to find out how and why mouse infestation disturbances can arise in a library. Then this study will look at how a library can preserve its collection against mouse infestation disturbances. 
This research is expected to add to the repertoire of knowledge about preserving collections against mouse infestations in the library and be used as a consideration for libraries in handling similar problems. Therefore, the function of a library as a cultural preservation institution can be achieved.

\section{Research Methods}

This research was conducted at the Indonesian Politics Study Center (PSBPI). PSBPI is an abbreviation of a faculty's library at a public tertiary educational institution in Indonesia. The object of this research was mouse infestation disturbances at PSBPI and the collection preservation activities done by PSBPI. A case study research method was utilized. A case study is an empirical inquiry which:

- researches phenomena in a real life context, when:

- limitations between phenomena and a context are not equivocally visible; and where:

- multi-source evidence is utilized. (Yin, 2014)

Research data was gathered through direct observations, interviews, and literature studies.

\section{Results and Discussion}

Mice are rodents which are frequently interrelated with human lives. According to Priyambodo (2003), mice can be utilized as laboratory research test subjects, but these rodents are more familiar as pests due to their destructive and disruptive nature. Mouse infestation disturbances can surface in buildings such as houses.

The kind of mouse which is commonly a pest in Indonesian homes is Rattus rattus diardii. This rodent is classified as a mammal, rodent order, myomorpha sub-order, muridae family, murinae sub-family, and R. Rattus genus (Walker in Permada \& Priyambodo, 2009). This mouse has the following characteristics: 
"It has a rather course fur texture, a cylindrical body, a conical shaped nose, large shaped ears with no fur inside and can close its eyes if it closes its eyelids, a grayish black stomach and back, a brownish black tail, a weight range of 60-300 grams, a tail measurement towards its head, and various body shapes (short, average, or long). Similar with tree shrews, house mice also have a skilled climbing ability. House mice have sharp senses which greatly assist them in doing their activities except for eyesight." (Permada \& Priyambodo, 2009)

Besides in the home, mouse infestation disturbances are also found in libraries. PSBPI is a library which has experienced this. The most dominant mouse infestation disturbances at PSBPI are in the form of mouse droppings and damage to furniture and electronic equipment from being bitten by mice. Mouse excrement and urine has been found in several rooms like the kitchen, storage room, and collection management room. According to Whitten, Emonsoeriaatmadja, \& Afiff (1996), mice can spread various dangerous diseases like leptospirosis, murine typhus, scrub typhus, rabies, trichinosis, and the plague. In addition, mice also frequently squeal and gnaw on items, so that it becomes noisy. Mice also urinate and leave their droppings around. Fortunately, the mouse infestation disturbances have not damaged the rack collections. The only collections which have experienced damage from mouse infestation disturbances are those kept in storage.

Arbi (a janitor at PSBPI) mentioned that the mouse infestation disturbances probably can occur because the mice enter through a ventilation hole of the PSBPI building. Actually, these holes should be closed tightly, so that mice cannot enter through them (Darmono, 2007). "Specifically, house mice can be controlled by using mechanical obstacles or barriers to prevent mice from entering a building or storage area." (Permada \& Priyambodo, 2009) These mice enter because they are attracted by the food and leftovers in PSBPI. The food and leftovers at PSBPI originate from employees who keep their food in the kitchen as well as from employees who quietly eat and drink inside PSBPI. Several times, Arbi found food and leftovers scattered around the floor because it was taken by mice. 
Purwanto (a librarian at PSBPI) believes that the mouse infestation at PSBPI is not yet at a troubling level. The mouse droppings can be quickly cleaned up by the cleaning service when PSBPI opens. A rather irritating problem is when mice damage the computer cables. The cables can be gnawed on by rats, and then the cables may not be replaced directly because they have to be ordered first. This can cause a disruption in library service and work, because the computer software cannot be used for a period of time.

Several actions have been taken by PSBPI related to these mouse infestation disturbances. Purwanto took the initiative to place moth balls in the room. In his opinion, after that there were no more signs of mice in the office. However, this was done personally and limited to the office but not the other rooms.

The next action taken was to use mousetraps. These mousetraps were borrowed from other work units, because PSBPI did not have any mousetraps. PSBPI did not have a special budget to purchase any mousetraps. Besides needing a budget, these mousetraps also have weaknesses.

"Using mousetraps to catch house mice is not considered very effective because mice have learned to avoid traps that are used in society. This makes it difficult to capture house mice with mousetraps. In addition, nowadays mice have adapted with mousetraps, so that they can easily avoid or escape capture." (Darmawansyah \& Priyambodo, 2008)

Another action that has been attempted is by using rat poison (rodentcide). This way is considered the "favorite" way, as an option to handle mouse infestation disturbances at PSBPI. This method can be used to eradicate several mice by using bait mixed with poison. "Poison and bait shyness need to be given attention when using rodentcide to get rid of mice, so that the effectiveness and efficiency of applying rodentcide can be considered." (Permada \& Priyambodo, 2009) Based on research conducted by Permada and Priyambodo (2009), the most effective way to eliminate house mice is by using flokumafen chronic rodentcide. This method is not without weaknesses, because occasionally it may be difficult to find the location of the poisoned mouse. This will cause an unpleasant odor to emanate from 
the rotting mouse carcass.

PSBPI has strived to minimize mouse infestation disturbances by setting out moth balls, affixing mousetraps, and using rat poison. These steps are done by PSBPI still related with the technical method of dealing with mouse infestation disturbances like the plan to use rat glue in several locations that are suspected of being mouse nests and to close holes that are thought to permit mice from entering the PSBPI building. The issue of handling the mouse infestation at PSBPI usually returns as a matter of discussion whenever a library staff member finds a disturbance caused by a mouse infestation. In other words, whenever there is an insignificant disturbance, PSBPI will not act to handle the mouse infestation.

Up until now, there are no procedures to handle mouse infestation disturbances at PSBPI. PSBPI also does not have a special section or staff in charge of preservation. The plan to handle the mouse infestation at PSBPI is often constrained with no budget provided for this. This does not reflect preservation activities overall because "Preservation covers all aspects of trying to preserve library materials and archives, including management policies, finances, human resources, methods, and recording techniques." (Sulistyo-Basuki, 1991)

\section{Conclusion}

Things that cause mouse infestation disturbances at PSBPI include having open ventilation holes, so that mice have a way into the building, and the presence of food and leftovers inside PSBPI. The kinds of damage resulting from a mouse infestation at PSBPI include damage to equipment, computer hardware, and books saved in storage that are gnawed on by mice. Besides that, mice make a mess of rooms by leaving urine and droppings all over the place.

This is not considered to be too much of a problem, because the library collections located on racks have not been damaged by mouse infestation disturbances. Only the old collections in storage have been damaged. These 
collections are no longer provided for library patrons.

This research reveals that PSBPI does not completely conduct preservation activities, whether in the case of mouse infestation disturbances or other factors which can damage the library collections. New preservation measures are taken after encountering cases of damage or potential collection damage. Preservation activities which are related with preservation management like policies, strategies, planning, and budgets have not been undertaken. Human resource development related with this problem also has not been prepared.

\section{References}

Darmawansyah, A., \& Priyambodo, S. (2008). Rancang bangun perangkap untuk pengendalian tikus rumah (Rattus rattus diardii Linn.) pada habitat permukiman. Institut Pertanian Bogor.

Darmono (2007). Perpustakaan sekolah: pendekatan aspek manajemen dan tata kerja. Jakarta: Grasindo.

Indonesia. Undang-Undang Nomer 43 Tahun 2007 Tentang Perpustakaan (2007). Indonesia.

Martoatmodjo, K. (1999). Buku materi pokok pelestarian bahan pustaka. Jakarta: Universitas Terbuka.

Muljono, P. (1996). Kerusakan buku di perpustakaan dan penanggulangannya: studi kasus di Institut Pertanian Bogor. Jurnal Perpustakaan Pertanian, $V(2), 51-58$.

Permada, J., \& Priyambodo, S. (2009). Tingkat kejeraan racun dan umpan pada tikus sawah (Rattus argentiventer Rob. \& Klo.), tikus rumah (Rattus rattus diardii Linn.), dan tikus pohon (Rattus tiomanicus ill.). Institut Pertanian Bogor.

Priyambodo, S. (2003). Pengendalian hama tikus terpadu (3rd ed.). Jakarta: Penebar Swadaya.

Rachman, Y. B. (2016). Dasar-dasar pelestarian. Depok: Universitas Indonesia. Sulistyo-Basuki. (1991). Pengantar ilmu perpustakaan. Jakarta: Gramedia 
Pustaka Utama.

Whitten, T., Emonsoeriaatmadja, R., \& Afiff, S. A. (1996). The ecology of Java and Bali: the ecology of Indonesia series Vol. II. Singapore: Dalhouise University.

Yin, R. K. (2014). Studi kasus: desain dan metode. Jakarta: Rajawali Pers. 